\title{
SIKLUS IDENTITAS SOSIAL SEBAGAI ADAPTASI IDENTITAS DIRI DARI PERAN YANG DIPANDANG SEBAGAI PENYIMPANGAN
}

Oleh:

Ivan Th.J. Weismann

\section{PENDAHULUAN}

\section{A. Latar Belakang}

Permulaannya manusia belum memiliki dirinya yang sudah terwujud, tetapi perlahan-lahan dirinya itu harus diwujudkan dalam kehidupannya yang unik. Manusia dalam proses perkembangan diri yang sejati secara sosial seringkali mengalami hambatan dan kemerosotan. Menurut Peter Homans (1973: 193)

"hambatan-hambatanyangdialamimanusiadalam prosespencapaiandirinyayang sejatiadalah sebagaiberikut: kemerosotankekuatan pribadi dan sosial; suatupemahamanyang berlebihan dan terlalu tinggiterhadap kesadaran diripribadi, yaitu dalam kesadaranyang terstruktur dan bermaknayang dikenal khususnya dalam konteks pribadi, personal, danpengalaman psikologi; dan timbulnya suatuperpecahan antara kesadaran diripribadidenganaturan sosial yang berakhir dalam suatu devaluasi struktur sosial sebagai suatu sumber dan objek komitmen pribadi."

Pencapaian diri yang sejati memampukan seseorang berfungsi sebagai orang dewasa yang sehat. Sebaliknya, kegagalan mencapai diri yang sejati di usia dewasa menimbulkan persoalan sosial maupun pribadi atau yang disebut pula sebagai penyimpangan sosial. Kegagalan pencapaian diri berperan penting dalam gangguan mental dan kepribadian, berkaitan dengan alkoholisme, penyalahgunaan obat terlarang, kekerasan dalam rumah tangga, korupsi, dan pelanggaran etika dan moralitas lainnya. Sebagai contoh diantaranya: Kapolres Tana Toraja dilapor atas tuduhan penganiayaan yang dilakukannya terhadap seorang warga di Rantepao (Harian Fajar, Selasa, 18 September 2007 halaman 26). Lebih lanjut antara lain tentang Kapolres Bantaeng dicopot Kapolda Sulsel karena memimpin langsung penyerangan terhadap anggota Yonif 700/Raider, di Bonto sunggu, Kabupaten Bantaeng. Buntutnya terjadi bentrokan antara oknum polisi dan TNI di daerah bergelar Butta Toa itu ( Fajar, Rabu, 17 Oktober 2007 halaman 1 dan 11). Kapolres Tana Toraja maupun Bantaeng adalah aparat negara yang beretugas mengayomi masyarakat tetapi justru melakukan penganiayaan dan penyerangan terhadap warga dan aparat lainnya.

Kegagalan pencapaian diri dinyatakan pula dalam perilaku menyimpang seperti korupsi. Perilaku menyimpang ini terjadi atas diri seorang yang dikenal sangat tegas dalam penegakan hukum. Beliau adalah anggota Komisi Yudisial, yang sebelumnya pernah menjabat sebagai Aspri Kajati Sumsel, Kasiintelijen Kejari Bengkalis, Kajari Pendeglang, Kajari Bandung, Kajari Bojonegoro, Kajati Kalimantan Tengah (Fajar, 27 September 2007: 1, 11). Beliau tertangkap tangan oleh penyidik 
Komisi Pemberantasan Korupsi saat menerima uang 874 juta terkait pengadaan tanah gedung Komisi Yudisial di jalan Kramat Raya No. 57. Seorang yang sudah benyak memiliki prestasi gemilang dalam menegakkan hukum dan dikenal pernah menolak suap sebesar 750 juta, namun kini terlibat dalam kasus menerima suap.

Perilaku menyimpang juga terdapat di kalangan akademisi. Penyimpangan itu berupa perilaku kekerasan. Sebagai contoh diantaranya ialah Pembantu Dekan III Fakultas Teknik Universitas Muhamadiyah (Unismuh) dipukul oleh oknum mahasiswa yang menjabat sebagai Ketua Badan Eksekutif Mahasiswa Fakultas Keguruan Ilmu Pendidikan Unismuh (Fajar, Senin, 24 September 2007 halaman 25). Lebih lanjut antara lain tentang mantan rektor Universitas " 45 " Makassar dituntut dua bulan penjara pada sidang di Pengadilan Negeri Makassar. Beliau dinilai terbukti mengirim pesan pendek elektronik bernada ancaman ke ponsel seorang pengusaha kayu di Makassar ( Tribun Timur, Kamis, 20 September 2007 halaman 12). Kasus yang lain lagi dalam kalangan akademisi ialah tentang dua dosen Fakultas Ilmu Sosial dan Politik Universitas Hasanuddin (Unhas) terlibat aksi adu jotos. Pasalnya, salah satu dosen menuduh lawannya melakukan praktik korupsi di kampus Unhas. Lantaran tidak tahan dengan tuduhan yang dilontarkan di muka umum, dosen yang dituding langsung memukul dosen yang menudingnya (Fajar, 6 November 2007, halaman 31). Ketiga kasus ini memperlihatkan baik mahasiswa maupun pemimpin perguruan tinggi dan beberapa dosen, dikenal sebagai orang terdidik dan maha terpelajar namun masih dapat memperlihatkan perilaku menyimpang.

Berikut ini kasus dari seorang selebritis terkenal Britney Spears diusir dari hotel mewah di kawasan Los Angeles. Britney makan dengan "membabi buta", cara makannya benar-benar menjijikan dan membuat pengunjung lain tidak nyaman (Fajar, 18 Septrember 2007: 32). Seorang yang terkenal di seantero jagad ini pun masih menperlihatkan penyimpangan perilaku di muka umum. Kenyataan menunjukkan bahwa sekalipun seseorang adalah aparat penegak hukum, pelindung pengayom masayarakat, berpendidikan, pendidik, pimpinan lembaga pendidikan yang tinggi, dan tokoh terpopuler di dunia dan kaya raya, namun atribut-atribut tersebut tidak memberikan jaminan bagi pemiliknya akan selalu dapat mengendalikan dirinya dari perilaku yang menyimpang. Teori hirarki kebutuhan Abraham Maslow mengatakan bahwa kebutuhan tertinggi manusia ialah aktualisasi diri (Robert Hogan dan Brent W. Roberts, 2004: 5). Ketika seorang mencapai aktualisasi diri ia mencapai kedewasaan dalam mengendalikan dirinya atas perilaku yang menyimpang. Aktualisasi diri menurut Sigmund Freud diukur dalam hal mengasihi (keharmonisan dalam rumah tangga) dan dalam hal bekerja (karir) (Robert Hogan dan Brent W. Roberts, 2004: 5). Kasus-kasus yang peneliti sebutkan di atas adalah mereka yang sudah mencapai aktualisasi diri dalam ruang lingkup rumah tangga dan karir. Ternyata fungsi aktualisasi diri bukanlah semata-mata sebagai pengendalian atas perilaku yang menyimpang. Pengendalian atas perilaku yang menyimpang tidak sepenuhnya berkaitan dengan kapasitas prestasi seseorang 
berupa pencapaian tujuan karirnya maupun terciptanya keharmonisan dalam rumah tangganya.

\section{B. Teori-teori Pencapaian Identitas Diri}

Teori pencapaian identitas diri adalah teori yang dapat menjadi alternatif dalam mengatasi persoalan yang berkaitan dengan peran karir yang sukses dan kemampuan pengendalian diri dari perilaku yang menyimpang. Adapun teori-teori tersebut adalah sebagai berikut:

\section{Jean Piaget}

Teori Piaget menggambarkan bagaimana proses sosialisasi dari lahir hingga awal remaja mengembangkan kemampuan anak untuk berpikir. Ada empat tahap perkembangan kemampuan berpikir anak yang harus dilewati. Piaget menyebut tahap-tahap itu: Sensorimotor antara usia 0 sampai 2 tahun, Pre-Operational anatara usia 2 hingga 5 tahun, Concrete Operations antara usia 6 hingga 10 tahun, dan Formal Opersations usia ll tahun ke atas. Penjelasan tahap-tahapini peneliti ringkaskan dari karya Neil J. Salkind yang berjudul Theories of Human Development, halaman 197-214 adalah sebagai berikut

Tahap sensorimotor disebut demikian karena bayi baru belajar menguasai anggota tubuhnya dan menafsirkan inderanya. Kemampuan berpikir bayi periode sensorimotor adalah belajar menguasai penerimaan inderawi (penglihatan, pendengaran, peraba, penciuman dan pengecap), dan bagimana menguasai gerakan anggota tubuh serta bagaimana memusatkan perhatian matanya. Tahap ini bayi berpikir bahwa segala sesuatu adalah dirinya. Dia belum mampu memisahkan dirinya dengan orang lain atau objek lain.

Selanjutnya adalah tahap pre-oprasional, pikiran anak mulai mengerti orang lain dan objek lain adalah terpisah dari dirinya, namun belum mengerti bagaimana hal-hal yang berbeda itu saling berhubungan. Sebagai contoh, seorang anak lakilaki mengerti dirinya adalah laki-laki, dan anak perempuan berbeda dengan anak laki-laki, tetapi dia berpikir bahwa dia dapat tumbuh menjadi anak perempuan. Tahap ini menggunakan istilah operasi dimaksudkan Piaget sebagai proses menggambarkan, memvisualisasikan atau membayangkan sesuatu dalam pikiran. Tahap ini anak hanya dapat mengingat suatu operasi seperti operasi penjumlahan namun belum mengerti bagaimana operasi penjumlahan itu berjalan.

Tahap konkrit operasional, anak sudah dapat mengerti jalannya operasi penjumlahan, pengurangan dan operasi lain yang lebih rumit. Kata konkrit adalah lawan dari abstrak. Tahap konkrit ini anak hanya dapat memahami operasi yang dapat dilihat atau dikerjakan secara fisik atau dengan bantuan alat. tetapi belum mampu mengopersikannya secara abstrak dalam pikirannya. Kempauan anak menjalankan operasi atas hal-hal yang abstrak atau yang tidak dilihat menandakan anak tersebut berada dalam tahap formal operasional. 
Keempat tahap perkembangan berpikir menurut Piaget ini mengajarkan beberapa hal. Pertama, pemahaman keanekaragaman dalam dunia ini diawali dengan terampil menguasai fungsi angota tubuh dan menafsir daya tangkap indera. Kedua, penguasaan prinsip operasi perhitungan dimulai dengan pengalaman yang konkrit dalam menghitung benda-benda yang konkrit. Ketiga, pemahaman perhitungan seeara abstrak diawali dengan memahami prinsip yang konkrit.

Tujuan akhir tahap perkembangan berpikir Jean Piaget ini ialah berpikir yang abstrak. Berpikir abstrak dimulai dari memahami dan mengalami hal-hal yang konkrit agar lebih dapat memahami dan mengalami hal-hal yang abstrak. Berpikir abstrak adalah lawan dari berpikir konkrit, artinya ialah kadangkala apa yang dipahami dengan eara berpikir konkrit atas segala hal berbeda ketika dipahami dengan cara berpikir abstrak. Contohnya, seorang yang berpikir konkrit selalu beusaha memenuhi kebutuhannya seperti menjauhi kesusahan dan mengejar kesenangan. Sebaliknya individu yang berpikir abstrak kadangkala lebih memilih kesusahan dan meninggalkan kesenangan demi pertumbuhan kedewasaan dirinya.

Teori Jean Piaget mengenai proses peneapaian identitas diri membahas pengembagan kemampuan berpikir yang dapat berguna bagi kemampuan mengenadalikan diri dari perilaku yang menyimpang. Akan tetapi teori Piaget ini hanya sampai pada kalangan remaja, sedangkan penelitian ini hendak meneliti pencapaian identitas di kalangan orang dewasa.

\section{Robert Kegan}

Jean Piaget membahas teori tahap perkembangan berpikir dalam proses sosialisasi, Robert Kegan mengemukakan teori kedewasaan sosial dalam proses sosialisasi. Kegan menjelaskan bahwa bayi bertumbuh menjadi dewasa melalui enam periode perkembangan yaitu incorporative, impulsive, imperial, interpersonal, institutional, dan interindividual. Tahap-tahap ini peneliti ringkaskan dari karya Mark Dombec, yang berjudul Robert Kegan's Awesome Theory of Social Maturity, diakses dari http:// MentalHelp. Net tanggal 22 Oktober 2007.

Periode inkorporatif, bayi sepenuhnya berpikir subjektif dan tidak memiliki pemikiran objektif. Bayi memiliki ide untuk menafsir sesuatu, dan dengan perspektifnya sendiri menafsir segala hal. Bayi mengenal wajah orang tuanya tetapi memikirkan orang tuanya sebagai bagian dari kebutuhannya bukan sebagai sesuatu mahluk yang lain. Tahap ini kesadaran bayi untuk memahami diri dan orang lain belum berkembang.

Periode impulsif, bayi sadar akan kebutuhannya, dan dapat mengambil tindakan untuk memenuhi kebutuhannya, walaupun harus melalui bantuan orang lain atau orangtuanya. Tahap ini bayi masih belum jelas bahwa orang lain itu sebgai mahluk yang independen.

Periode imperial, diri anak tidak lebih dari seperangkat kebutuhan. Kesadaran anak akan kebutuhan membuat dia juga dapat sadar untuk memanipulasi segala hal 
untuk mendapatkan kepuasan kebutuhannya. Tahap ini anak sadar akan kebutuhannya tetapi tidak sadar bahwa orang lain juga memiliki kebutuhan.

Tahap interpersonal, anak mengerti bahwa ada orang lain yang memiliki kebutuhan untuk dipenuhi di samping dirinya. Anak mulai menghargai orang lain. Kesadaran akan rasa bersalah, malu dan berempati mulai timbul.

Tahap institutional, anak menyadari suatu prinsip yang menolong menentukan apa yang menjadi prioritas. Tahap ini anak mulai memiliki nilai, komitmen dan prinsipyang lebih permanen untuk mengembangkan diri dalam kehidupan lembaga masyarakat. Menurut Kegan kedewasaan sosial individu tidak berhenti sampai di sini, yaitu sekedar menjadi anggota masyarakat yang "baik", "jujur", "adil", dan"berani".

Tahap berikut ialah interindividual, seseorang mulai belajar keanekaragaman sistem nilai di samping sistem nilainya sendiri. Seseorang yang mencapai kedewasaan sosial interindividual dapat berpegang pada sistem nilainya sendiri namun pada saat yang sama juga berpegang pada sistem nilai lintas budaya, dan melihat persoalan dari berbagai perspektif tersebut.

Identitas sosial menurut Kegan berkembang dari pengertian diri yang paling sederhana menuju pengertian diri yang semakin kompleks atas dunia sosial. Kedewasaan itu dimulai dari perspektif subjektif, yaitu melihat segala hal dari titik pandangnya sendiri, dan tidak dapat memahami apa yang seharusnya dilihat dari perspektif orang lain selain dari perspektifnya sendiri. Kedewasaan itu menuju kepada perspektif objektif yaitu mampu mengapresiasi segala hal dari perspektif yang berbeda, dan yang lebih luas, atau mampu memahami perspektif orang lain dan memiliki perspektif tersebut.

Teori identitas sosial Robert Kegan sangat baik membahas perkembangan kemampuan individu mengatasi perilakunya yang menyimpang. Akan tetapi menurut penjelasan Kegan perlu menunggu anak memasuki usia yang lebih dewasa maka ia bisa berada pada tahap yang lebih mampu mengatasi perilakunya yang menyimpang di usia sebelumnya. Penelitian ini menghendaki dalam proses pencapian identitas diri sekaligus terkandung kemampuan mengatasi perilaku yang menyimpang pada usia yang dijalaninya.

\section{Erik Erikson}

Proses pencapaian identitas diri berupa perspektif mengalami perubahan seiring dengan pertambahan usia, adanya pengalaman dan informasi baru. Perubahan-perubahan tersebut dikemukakan Erikson dalam pengertiannya tentang perkembangan identitas ego yang dijelaskan oleh Kendra Van Wagner dalam artikelnya yang berjudul Psychosocial Development in Infancy and Early Childhood diakses dari http://psychology.about.com/od/theories of personality/a/psychosocial.htm tanggal 22 Oktober 2007.

Menurut Erikson pencapaian identitas diri ialah perkembangan identitasego. Identitas ego ialahalam sadar diriyang berkembanganmelalui interaksi sosial. Idenstitasego selalu mengalami 
perubahan sesuai dengan pengalaman dan informasi baru yang diperoleh dalam interaksi kesehariandenganoranglain. Identitas egomengandung kompetensiyang memotivasiperilaku dan tindakan. Perkembagan identitas ego seiring dengan perkembangan kompetensi dalam setiapaspek kehidupan. Jika tahap perkembangan berlangsung lancar, seseorang akan merasa berkompetensi. Jika tahap perkembangan mengalami hambatan, seseorang akanmerasa tidak kompeten. Setiaporangmengalami konflikyang berfungsi sebagai titikawal dalam setiap tahap perkembangan. Konflik dapat berpotensil untuk pertumbuhan kualitas pribadi, dapat pula berpotensikegagalan.

Erikson berpendapat bahwa perkembangan identitas diri melalui tahap-tahap perkembangan psikososial, dan setiap tahap ada konflik yang menentukan seseorang menuju kedewasaan atau kemunduran atau menjadi mandeg. Menurut Erikson perkembangan identitas diri melalui serangkaian tahap-tahap perkembangan psikososial. Tahap-tahap tersebut mengambarkan pengaruh pengalaman sosial dalam seluruh kehidupan. Setiap tahap menentukan kompetensi identitas diri seseorang. Setiap tahap mengandung pengalaman konflik, jika ditangani dengan berhasil akan akan mengembangkan kualitas identitas diri, jika tidak berhasil seseorang akan gagal mengembangkan kualitas identitas dirinya. Tahap-tahap tersebut digambarkan dalam bagan berikut ini (Salkind, 1981: 93):

\begin{tabular}{|c|c|c|c|}
\hline Tahap & Konflik Dasar & $\begin{array}{c}\text { Peristiwa } \\
\text { penting }\end{array}$ & Hasil \\
\hline $\begin{array}{c}\text { Bayi } \\
\text { (lahir hingga } \\
18 \text { bulan) }\end{array}$ & $\begin{array}{c}\text { Keprcayaan } \\
\text { vs. } \\
\text { Ketidakpercayaan }\end{array}$ & Menyusu & $\begin{array}{l}\text { Anak akan mengembangkan } \\
\text { rasa percaya ketika } \\
\text { pengasuhnya memberikan } \\
\text { kepedulian, afeksi, rasa aman } \\
\text { dan penerimaan. Kekurangan } \\
\text { hal-hal tersebut menimbulkan } \\
\text { ketidakpercayaan dalam diri } \\
\text { anak. }\end{array}$ \\
\hline $\begin{array}{c}\text { Batita } \\
\text { (2 hingga } 3 \\
\text { tahun) }\end{array}$ & $\begin{array}{l}\text { Otonomis } \\
\text { vs. Minder dan } \\
\text { keragu-raguan }\end{array}$ & $\begin{array}{c}\text { Pelatihan } \\
\text { membuang } \\
\text { urine dan feses }\end{array}$ & $\begin{array}{l}\text { Anak perlu belajar } \\
\text { mengendalikan fungsi } \\
\text { tubuhnya dan memilih sendiri } \\
\text { makanan, pakaian dan mainan } \\
\text { untuk mengembangkan } \\
\text { pengendalian diri dan } \\
\text { kemandirian. Kegagalan } \\
\text { dilam hal ini menimbulkan } \\
\text { rasa minder dan penuh } \\
\text { keragu-raguan. }\end{array}$ \\
\hline
\end{tabular}




\begin{tabular}{|c|c|c|c|}
\hline $\begin{array}{c}\text { Prasekolah } \\
\text { (3 hingga } 5 \\
\text { tahun) }\end{array}$ & $\begin{array}{c}\text { Inisiatif } \\
\text { vs. } \\
\text { Rasa bersalah }\end{array}$ & Eksplorasi & $\begin{array}{l}\text { Anak perlu mulai tegas dalam } \\
\text { mengendalikan dan memimpin } \\
\text { lingkungan melalui } \\
\text { menggarahkan permainan dan } \\
\text { interaksi sosial lainnya untuk } \\
\text { mengembangkan kemampuan } \\
\text { memimpin orang lain. } \\
\text { Kegagalan dalam hal ini } \\
\text { menimbulkan rasa bersalaah, } \\
\text { tidak percaya diri, dan kurang } \\
\text { inisiatif. }\end{array}$ \\
\hline $\begin{array}{c}\text { Usia sekolah } \\
\text { (6 hingga } 11 \\
\text { tahun) }\end{array}$ & $\begin{array}{c}\text { Industri } \\
\text { vS. } \\
\text { inferioritas }\end{array}$ & Bersekolah & $\begin{array}{l}\text { Anak perlu menuruti tuntutan } \\
\text { akademik dan sosial yang baru } \\
\text { untuk mengembangkan } \\
\text { perasaan kompetensi dan } \\
\text { keyakinan akan } \\
\text { ketrampilannya. Kegagalan } \\
\text { dalam hal ini menimbulkan } \\
\text { rasainferioritas. }\end{array}$ \\
\hline $\begin{array}{c}\text { Remaja } \\
\text { (12 hingga } 18 \\
\text { tahun) }\end{array}$ & $\begin{array}{l}\text { Identitas } \\
\text { vs. } \\
\text { Kekacauan } \\
\text { peran }\end{array}$ & $\begin{array}{l}\text { Hubungan } \\
\text { sosial }\end{array}$ & $\begin{array}{l}\text { Remaja perlu mengmbangkan } \\
\text { identitas diri dengan yakin } \\
\text { akan kepercayaan dan } \\
\text { keinginannya. Kegagalan } \\
\text { dalam hal ini membuat remaja } \\
\text { tidak yakin dan bingung } \\
\text { tentang diri dan masa } \\
\text { depannya. }\end{array}$ \\
\hline $\begin{array}{c}\text { Dewasa muda } \\
\text { (19 hingga } 40 \\
\text { tahun) }\end{array}$ & $\begin{array}{l}\text { Keintiman } \\
\text { vs. } \\
\text { Memisihkan } \\
\text { diri }\end{array}$ & $\begin{array}{l}\text { Hubungan } \\
\text { Relasional } \\
\text { yangintim }\end{array}$ & $\begin{array}{l}\text { Dewasa muda perlu hubungan } \\
\text { intim dan kasih sayang dengan } \\
\text { orang lain untuk } \\
\text { mengembangkan keintiman } \\
\text { dalam hubungan. Kegagalan } \\
\text { dalam hal ini ialah kurang } \\
\text { mampu membina hubungan } \\
\text { yang intim, dan menderita } \\
\text { depresi, kesendirian, dan } \\
\text { memisahkan diri. }\end{array}$ \\
\hline
\end{tabular}




\begin{tabular}{|c|c|c|l|}
\hline $\begin{array}{c}\text { Paruh baya } \\
\text { (40 hingga 65 } \\
\text { tahun) }\end{array}$ & $\begin{array}{c}\text { Produktivitas } \\
\text { vs. } \\
\text { Stagnasi }\end{array}$ & $\begin{array}{c}\text { Bekerja dan } \\
\text { menjadi } \\
\text { orang tua }\end{array}$ & $\begin{array}{l}\text { Paruh baya perlu membangun } \\
\text { kehidupannya, fokus pada } \\
\text { keluarga dan karir agar aktif } \\
\text { dalam keluarga dan } \\
\text { masyarakat. Kegagalan dalam } \\
\text { hal ini akan menimbulkan rasa } \\
\text { tidak berguna dan keengganan } \\
\text { terlibat dalam dunia. }\end{array}$ \\
\hline $\begin{array}{c}\text { Dewasa lanjut } \\
\text { usia(65 hingga } \\
\text { meninggal) }\end{array}$ & $\begin{array}{c}\text { Integritas ego } \\
\text { vs. }\end{array}$ & $\begin{array}{c}\text { Keputusasaan } \\
\text { kehidupan }\end{array}$ & $\begin{array}{l}\text { Orang dewasa yang sudah } \\
\text { lanjut perlu mengenang masa } \\
\text { lalu hidunya dan merasa puas } \\
\text { dan bangga agar dapat } \\
\text { mencapai hikmat, integritas } \\
\text { diridan siap menghadapi } \\
\text { kematian. Kegagalan dalam } \\
\text { hal ini akan mengisi } \\
\text { kehidupannyadengan } \\
\text { perasaan penyesalan dan } \\
\text { kesia-siaan atas segala } \\
\text { pengalaman kehidupan masa } \\
\text { lalunya }\end{array}$ \\
\hline
\end{tabular}

Sama seperti Piaget dan Kegan, Erikson mengemukakan teori pencapaian identitas diri bahwa identitas diri, kedewasaan diri atau kemampuan mengendalikan konflik dan perilaku yang menyimpang akan tercapai ketika individu mencapai usia yang lebih dewasa bahkan ketika sudah lanjut usia. Teori-teori pencaipaian identitas diri yang dibahas di atas semuanya berimplikasi bahwa sebelum individu mencapai usia dewasa, ia belum memiliki kemampuan mengendalikan konflik maupun perilakunya yang menyimpang

\section{Rumusan Masalah}

Adapun rumusan masalah dalam kajian iniialah merumuskan teori pencapaian identitas diri yang dapat menolong individu baik kanak-kanak, remaja dan dewasa untuk mengendalikan konflik dan perilakunya yang dianggap menyimpang oleh masyarakat. Kajian ini secara khusus merumuskan teori pencapaian identitas diri yang dapat menolong para pemimpin religius dalam mengendalikan konflik antara dirinya dengan masyarakat yang memandang kegiatan pelayanannya seperti penyembuhan dan pengusiran setan sebagai penyimpangan atau dicap/dilabel scbagai praktek paranormal atau perdukunan. 
A. Peran Pemimpin Religius yang dipandang sebagai Penyimpangan

Ada beberapa model kepemimpinan religius yang fungsi dan perannya dipandang sebagai perilaku yang menyimpang

\section{Shaman (dukun/cenayang)}

Shaman menggunakan kuasa untuk mendiagnosa dan mengobati penyakit atau menenangkan dewa-dewa yang marah (Nida, 1982: 160). Pemimpin agama dalam masyarakat skala kecil (Rosman dan Paula G Rubel, 1985: 175) mendengar panggilan dari dewa/roh atau dari dukun tertinggi. Suara-suara yang mereka dengar menandakan mereka adalah orang yang mempunyai keahlian khusus dalam masyarakat tersebut (Ellwood, 1982: 48). Untuk mendapatkan kuasa dan memenuhi panggilan mereka sebagai shaman harus melalui penderitaan-penderitaan atau kesulitan-kesulitan (Lommel, 1983:11-12). Haviland mencatat bahwa para pemimpin agama yang mempraktekkan kesembuhan ilahi banyak kemiripan dengan praktisi religius perdukunan (Haviland, 1983: 358).

2. Penyihir/tukang santet

Penyihir atau tukang santet menggunakan kuasa mereka untuk kejahatan dari pada kebaikan, yaitu menyebabkan penyakit atau kematian (Nida, 1982:10). Dia yang menyebabkan penyakit tertentu aka dia pula yang dapat menyembuhkannya. Tukang santet ini dapat berperan pula sebagai dukun. Dengan kuasanya juga dapat menyebabkan gagal panen, kemalangan dalam hal rejeki atau bencana-bencana lainnya (Winick, 1956: 559). William Lessa dan Evan Vogt (1979: 333) mengatakan, "unsur-unsur mengerikan" dalam sisi penyihir atau tukang santet semakin menumpukkan ketakutan dan bencana dalam dirinya sendiri. Fenomena ini biasanya adalah keahlian yang diwariskan dan ada juga yang dipelajari (Rosman dan Rubel, 1985: 177).

\section{Peramal}

Peramal mencari informasi dari sumber-sumber supernatural untuk membantu klien menentukan pilihan terbaik tentang tindakan di masa depan. Mereka menggunakan berbagai teknik ilmu gaib:

memerikasa isi perut hewan (haruspicy), membaca retakan-retakan darilumpur kering (geomancy), melihat hal-hal yang tidakdapat dilihat denganmatanormal (clairvoyancc) dan menentukan karakter dari bentuk kepala seseorang (phrenology), petangan (numerology) menghitung hari haribaik untuk memulai usaha yang beresiko, kawin, bepergian (Rakoczi, 1985:652-660).

4. Perantara yang kerasukan roh-roh/mahluk halus

Biasanya golongan ini kebanyakan wanita. Kuasa mereka berasal dari satu atau lebih roh-roh yang merasukinya (Kimbal, Linda Amy, Dale McGinnis, Shawna Craig, 1986: 129-130). Orang yang menolak panggilan untuk menjadi perantara 
kerasukan roh-roh akan sakit atau lumpuh, kecuali dia dapat menenangkan roh-roh yang ingin merasuknya. Umumnya mereka yang melayani sebagai penyambung lidah roh-roh mengalami pecahnya kepribadian kesadaran. Biasanya mereka tidak dapat mengingat kembali apa yang dialami ketika tidak sadar (Francis King, "trance", 1985: 2867-2870). Gejala perilaku yng dinyatakan ketika kerasukan roh berupa tertawa terbahak bahak, menangis atau menggelepar (Murphy, 1986: 181).

5. Pawang

Pawang digunakan untuk kepentingan masyarakat, seperti mendatangkan hujan, melindungi kampung, membantu dalam memancing. Pawang menggunkan mantera-mantera,jimat-jimat untuk mendukung kekuatan-kekuatan yang tidak terlihat untuk mengikuti tuntutan pawang (Nida, 1978: 8). Richard Covendish (1985: 1683) menekankan bahwa tujuan uatma pawang adalah kuasa tertinggi atas sehala sesuatu, kemahakuasaan yang tak tertandigi.

6. Pertapa (mistik)

Pertapa tunduk pada pemerintahan dari dunialain. Pawang sebagai pengirim pesan kepada kekauatan-kekuatan yang kelihatan. Pertapa menerima atau sebagai saluran wahyu ilahi. Pawang mengendalikan kuasa-kuasa. Pertapa ketika dirasuk menuruti petunjuk-petunjuk dengan sukacita dan kerendahan hati (Nida, 1978: 78)

\section{B. Sosiologi Penyimpangan}

Sosiologi penyimpangan ialah kajian sosiologi atas perilaku menyimpang, kejahatan atas norma budaya, dan penciptaan serta pemaksaan norma-norma. Penyimpangan sosiologi berkaitan dengan, dan juga berbeda dengan bidang kriminologi. Sosiologi penyimpangan mempertimbangkan penyimpangan sebagai suatu konsep yang relatif. Jika penyimpangan adalah mutlak maka, semua masyarakat, pada sepanjang jaman, akan memeprtimbangakan bentuk-bentuk perilaku tertentu sebagai penyimpangan. Setiap masyarakat mengembangkan aturan yang melarang bentuk-bentuk perilaku tertentu sebagai memiliki sifat penyimpangan. Sebaliknya, penyimpangan didefinisikan dalam istilah relatif berarti bahwa masyarakat yang berbeda pada jaman yang berbeda mengembangkan cara yang berbeda dalam melihat bentuk perilaku yang sama. Definisi relatif ini menunjukkan bahwa tidak ada satupun "penyebab" bagi perilaku. Karena ada perbedaan cara dalam mendefinisikan bentuk perilaku yang sama. Berikut ini adalah beberapa teori penyimpangan.

\section{Teorilebeling}

Teori labeling dipelopori oleh Edwin Lemert. Teori penyimpangan menyarankan bahwa penyimpangan disebabkan olch orang yang menyimpang dilebel (pemberian julukan, cap, etiket, merek) secara negatif, menginternalisasi lebel itu, dan berbuat menurut lebel tersebut. Sebagai contoh, jika seorang guru melebel 
seorang siswa sebagai anak bandel, siswa menginternalisasi lebel itu dari figur yang memiliki otoritas dan berlaku sebagaimana lebel itu adalah nubuat yang berlaku atas dirinya. Teori lebel juga memiliki unsur teori konflik seperti pada kelompok yang berkuasa memutuskan mengenai apa yang menyimpang dan dapat diterima, dan menukmati kekuasaan di balik proses lebeling itu. Sebagai contoh, suatu sistem dalam penjara yang melebel seorang yang divonis sebagai pencuri, maka orang tersebut mulai memandang dirinya sebagai pencuri (http://en.wikipedia.org/wiki/ Sociology of deviance. hlm 2).

Mula-mula seseorang melakukan suatu penyimpangan, yang oleh lemert dinamakan penyimpangan primer atau primary deviation. Akibat dilakukannya penyimpangan tersebut, si penyimang lalu diberi cap. Sebagai tangapan terhadap pemberian cap oleh orang lain maka si pelaku penyimangan primer kemudian mendefinisikan dirinya sebagai penyimpang dan mengulangi lagi perbuatan menyiangnya - melakukan penyimpangan sekunder atau secondary deviation sehingga mulai menganut suatu gaya hidup menyimpang atau deviant life style yang menghasilkan suatu karier menyimpang atau deviant career (Sunarto, 1993)

2. Teori konflik

Para ahli teori konflik melihat penyimpangan sebagai akibat konflik antara individu-individu dan kelompok-kelompok-kelompok. Mereka yang memiliki kuasa berkompeten menciptakan norma dan lebel bagi para penyimpang. Perilaku menyimpang seringkali adalah akibat struktur sosial yang ada mencegah kelompok minoritas untuk memiliki jalan masuk pada sumber daya yang terbatas. Oleh karena itu maka penyimpangan sebagai suatu reaksi yang menghasilkan konflik antara kelompok-kelompok dan individu-individu untuk mendapatkan sumber daya terbatas. Definisi ini untuk menjelaskan penyimpangan oleh warga miskin, bukan untuk memahami kejahatan yang dilakukan oleh pekerja kerah putih. Definisi ini juga menetapkan bahwa orang yang berkuasa yang mendefinisikan kejahatan.

3. Teori biologis

Cesare Lombroso menetapkan bahwa beberapa orang secara genetik telah ditetapkan untuk perilaku kriminal. Kriminal adalah produk dari bentuk genetik. Bentuk genetikitu membuat seseorang dilahirkan sebagai kriminal, yang sulit untuk diobati karena diturunkan secara biologis.

\section{Teori strain (tekanan)}

Robert K. Merton membahas penyimpangan dalam isitilah tujuan dan sarana sebagai bagian dari teori anomi/strain. Merton mencoba menjelaskan penyimpangan sosial pada jenjang makro, yaitu pada jenjang struktur sosial. Menurut argumen Merton sturktur sosial tidak hanya menghasilkan perilaku konformis, tetapi menghasilkan pula perilaku menyimpang; struktur sosial menciptakan keadaan yang menghasilkan pelanggaran terhadap aturan sosial; menekan orang-orang tertentu ke arah perilaku nonkonform (Kamanto Sunarto, 1993). 
Merton mengatakan bahwa respon individu atas harapan masyarakat dan sarana yang digunakan individu untuk mencapai tujuan adalah penting untuk memahami penyimpangan. Tindakan kolektif yang menimbulkan strain, stress atau frustrasi dalam diri individu menimbulkan suatu pemutusan hubungan anatra tujuan masyarakat dan sarana yang digunakan secara umum untuk mencapai tujuan tersebut (Http://en.wikipedia.org/wiki/sociology of deviance. halaman 2).

Merton mengidentifikasi lima tipe cara adaptasi individu terhadap situasi tertentu; empat diantara lima perilaku peranan dalam menghadapi situasi tersebut merupakan perilaku menyimpang. Cara adaptasi pertama, konformitas merupakan cara yang paling banyak dilakukan. Perilaku mengikjuti tujuan yang ditentukan masyarakat, dan mengikuti cara yang ditentukan masyarakat untuk mencapai tujuan tersebut.

Cara adaptasi kedua, inovasi merupakan cara perilaku mengikuti tujuan yang ditentukan masyarakat tetapi memakai cara yang dilarang oleh masyarakat. Cara ketiga, ritualisme ialah perilaku seseorang telah meninggalkan tujuan budaya namun masih tetap berpegang pada cara-cara yang telah digariskan masyarakat. Retretisme (pengunduran diri) merupakan bentuk adaptasi berikutnya yaitu perilaku seseorang tidak mengikuti tujuan budaya dan juga tidak mengikuti cara untuk meraih tujuan budaya. Pemberontakan merupakan bentuk adaptasi terakhir, yaitu orang tidak mengakui struktur sosial yang ada dan berupaya menciptakan suatu struktur sosial yang lain.

Tabel Teori Strain/Tekanan

\begin{tabular}{|c|c|c|}
\hline & Menerimatujuan & Menolak tujuan \\
\hline Menerima cara/sarana & Konformitas & Ritualisme \\
\hline Menolakcara/sarana & Inovasi & $\begin{array}{c}\text { Retreatismedan } \\
\text { Pemberontakan }\end{array}$ \\
\hline
\end{tabular}

Penerimaan tujuan dan sarana didefinisikan sebagai konformitas (contoh, berbisnis untuk mendapat kekayaan). Penerimaan tujuan dan penolakan sarana digambarkan sebagai inovasi, yang dapat menjadi positf atau negatif (contoh, mendaparykan kekayaan dengan merampok adalah negatif, sedangkan menciptakan bisnis baru adalah metode positif). Penolakan tujuan dan penerimaan sarana adalah ritualisme. Penolakan tujuan maupun sarana adalah retreatisme - seorang tuna wisma. Pemberontak adalah orang yang menolak tujuan dan sarana dan menggantikannya dengan sistem lain yang dapat diterima 


\section{Teori Kontrol}

Teori ini menekankan ketika ikatan anatra individu dan masyarakat lemah membuat orang menyimpang. Sebaliknya, ketika ikatan kuat maka penyimpangan sangat beresiko. Teori kontrol berkembang ketika norma menghambat perilaku menyimpang. Tanpa "kontrol" ini perilaku menyimpang akan sering terjadi. Orang akan taat pada kelompok ketika mereka yakin mereka mendapat banyak hasl dari ketaatan dari pada penyimpangan. Seseorang akan menuruti norma ketika memiliki ikatan yang kuat dengan masyarakat. Ikatan terdiri atas empat faktor: komitmen, kasih sayang, keyakinan dan keterlibatan. Ketika salah satu faktor ini melemah atau diabaikan amaka seseorang akan melakukan penyimpangan. (contoh, seseorang akan enggan untuk menyimpang setelah bekerja keras untuk mendapatkan gelar doktor karena resiko yang ditanggung akan terlalu besar)

\section{Asosiasi Diferensial}

Edwin $\mathrm{H}$. Sutherland mengemukakan bahwa semua perilaku adalah akibat sosialisasi melalui interaksi (Rodney Starke, 2007. Sociology: Tenth Edition. Belmont, CA. Thomson Wadsworth 188). Seseorang bertindak sesuai dengan orang yang berasosiasi dengannya. Jika tindakan didorong kembali oleh kelompok yang berasosiasi dengannya, tindakan itu cenderung diulangi, jika perhatian dan penghargaan diberikan. Contohnya, jika seorang anak memutuskan untuk memecahkan kaca jendela, dan kawan-kawannya mendukung tindakannya, anak itu akan meneruskan perbuatan penyimpangan itu. Robert Burgess dan Ronbald Akers mengemukakan mengenai teori pembelajaran sosial. Mereka mengatakan bahwa satu anggota keluarga akan melakukan kegiatan kriminal, jika anggota keluarga lain sudah melaukannya (Starke, 2007: 188). Variabel yang penting dalam teori ini ialah usia dari orang yang belajar menyimpang, kualitas hubungan antara yang belajar menyimpang dengan model yang memerankan penyimpangan, dan relasi anatra yang belajar dan model pelaku penyimpang. Menurut Sutherland penyimpangan bersumber pada different association (pergaulan yang berbeda). Penyimpangan dipelajari melalui proses alih budaya (cultural transmission). Melalui proses belajar ini, seseorang mempelajari suatu deviant subculture (kebudayaan menyimpang) (Kamanto Sunarto, 1993)

\section{Fungsionalisme}

Fungsionalisme memandang penyimpangan sebagai sesuatu yang diburuhkan oleh masyarakat. Penyimpangan menguji batas-batas dan menegaskan kembali norma-norma sosial. Penyimpangan juga menyediakan lapangan kerja bagi dokter, penegak hukum, pekerja sosial, politisi, pemimpin agama, dan seterusnya.

Menurut Durkheim, masyarakat didasarkan pada membagi nilai-nilai umum (kesadaran kolektif) di kalangana mereka yang menjadi dasar tindakan. Pada masa perubahan atau tekanan sosial, kesadaran kolektif manjadi lemah. Masyarakat dalam situasi ini akan hidup menurut kepentingannya sendiri dari pada menuruti nilai- 
nilai sosial. Durkheim menyebut situasi ini sebagai anomi. Fungsionalisme menegaskan bahwa penyimpangan akan berfungsi menciptakan kohesi diantara anggota dalam kalangan suatu kelompok masyarakat.

\section{Penyimpangan Medis}

Penciptaan lebeling atas para penyimpang telah berpindah dari lembaga agama ke lembaga medis. Peralihan ini disebabkan oleh bertambahnya penjelasan ilmiah dan medis atas perilaku para pennyimpang. Contohnya, seorang dengan ganguan mental menuut penjelasan agama dianggap sebagai kerasukan atau kepenuhan kekuatan supernatural. Akan tetapi, penyimpangan medis yang menyebabkan persoalan mental atau persoalan kesehatan lain dijelaskan secara medis, akan memberi pengaruh pada peran yang dimainkan pasien. Seseorang yang dilebeling sakit mental akan memerankan "peran sakit mental" agar pelanggarannya atas norma dapat diampuni sepanjang ia dipamndang oleh paramedis sebagai penderita sakit mental.

\section{Adaptasi atas Penyimpangan melalui Siklus Identitas Sosial}

1. Teori daptasi atas Lebel Penyimpangan

Umumnya pemimpin religius dalam menjalankan perannya berkaitan dengan penyimpangan lebel. Pemimpin religius yang memberikan pelayanan kesembuhan atau pengusiran setan sering dicap sebagai paranormal atau dukun. Yesus Kristus dalam Matius 12:22-37; Markus 3:20-30; Lukas 11:14-23 ketika menjalankan perannya menyembuhkan seorang yang kerasukan setan, buta dan bisu, dituduh oleh orang Farisi, bahwa Yesus mengusir setan dengan penghulu setan.

Menurut J. W. Rogers dan M. D. Buffalo ada 9 cara adaptasi ketika peran yang dimainkan seseorang mendapat lebel penyimpangan dari masyarakat. 9 cara itu bergantung pada 3 reaksi dari orang yang mendapat lebel penyimpangan yaitu persetujuan, penolakan dan pertukaran. Cara adaptasi juga bergantung pada 3 reaksi masyarakat yang memberi lebel yaitu pengagungan, manipulasi dan pemusnahan. 9 cara adaptasi itu seperti yang dikutip oleh Santiago Guijaro (1999) ialah sebagai berikut:

\begin{tabular}{|l|l|l|l|}
\hline & Pengagungan & Manipulasi & Pemusnahan \\
\hline Persetujuan & Menyetujui tanpa protes & Penyaluran & Reinterpretasi \\
\hline Penolakan & Tidak mengakui & Penghindaran & Redefinisi \\
\hline Pertukaran & Melarikan diri & Modifikasi & Perubahan \\
\hline
\end{tabular}

9 cara adaptasi atas penyimpangan lebel ini dapat dihubungkan satu dengan yang lainnya menjadi satu ramgkaian adaptasi yang berkesinambungan. Jika demikian, rangkaian adaptasi itu serupa dengan model siklus identitas sosial berikut ini. 


\section{Siklus Identitas Sosial}

Siklus identitas sosial dikemukakan oleh Robert E. Kleine, III dan Susan Schultz Kleine. Ada beberapa tahap siklus identitas sosial menurut Kleine: prasosialisasi, penemuan (kembali) atau (re) discovery, konstruksi (kembali) atau (re) construction, pemantapan atau maintenance, latensi dan penhyusunan/pengaturan atau disposition. Adapun kerangkanya sebagimana yang digambarkan oleh Kleine dalam artikelnya yang berjudul Consumption and Self-Schema Changes Throughtout the Identity Project Life Cycle yang diakses tanggal 28 Februari 2008 dari http:// greenspun.com/com/GentlEye/articles/id cycle/id cycle2.html. adalah sebagai berikut:

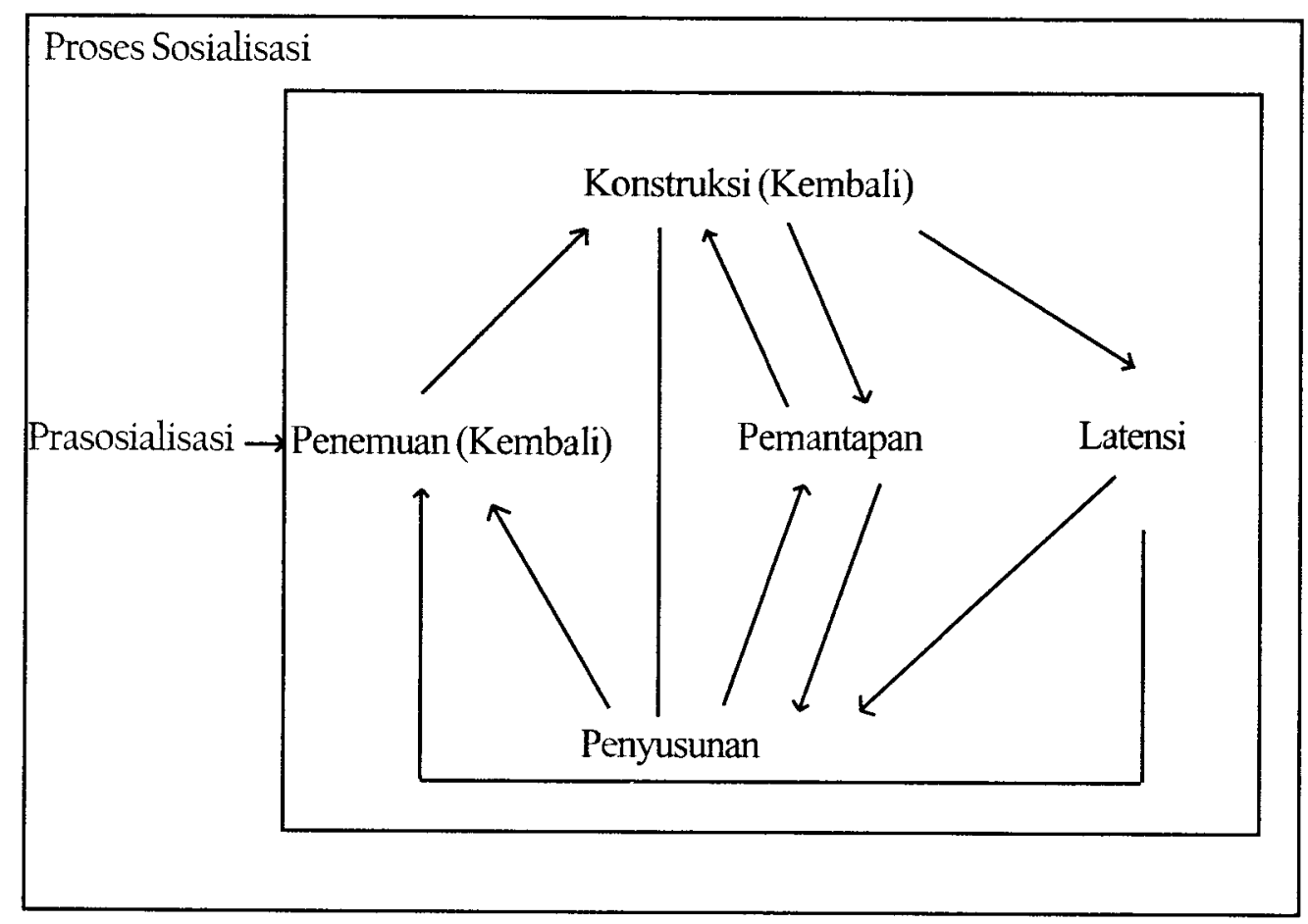

Berikut ini adalah pembahasan siklus identitas sosial sebagai adaptasi atas identitas diri dari peran para pemimpin religius dalam menjalankan praktek penyembuhan dan pengusiran setan yang dipandang sebagai penyimpangan atau praktek paranormal atau perdukunan.

\section{a. Prasosialisasi}

Prasosialisasi bertujuan mencapai suatu identitas. Identitas ialah penempatan seseorang dalam suatu situasi sosial. Identitas bukan subtitusi dari diri. Seseorang memiliki identitas ketika dia disituasikan atau dibentuk oleh situasi soial melalui partisipasinya dalam relasi sosial (Mackie, 1987: 121-122)

Identitas juga adalah peran yang menunjuk pada harapan perilaku yang dituntut untuk dikerjakan yang berkaitan dengan posisi. Peran adalah seperangkat norma sosial yang mengatur perilaku seseorang dalam suatu kelompok dan 
menentukan hubungan dengan anggota kelompok lainnya. Ada bebrapa konsep tentang peran:

Belajarperan, yaitu proses orang belajar peran dan bagaimana memainkannya. Menjalankan peranadalah perilakuyang tertanam dalam dirinyaketika menjalankan suatuperan. Empati peran adalah prosesorang belajar mengalami ideatauperasaanoranglain (Geral R Leslie, R. F. Larson dan B. L. Gorman, 1980: 151-153).

Memiliki identitas berarti seseorang disituasikan oleh dirinya dan orang lain dalam pengertian sosial (Mackie, 1987: 121-122). Prasosialisasi identitas adalah akibat dari proses sosialisasi yang dialami anggota dalam kelompok masyarakat tertentu. Prasosialisasi terjadi lama sebelum seseorang secara aktif menjadi tertarik, atau mencapai suatu identitas. Melalui sosialisasi, individu belajar mengambil dan memainkan peran dan meggunakan pola-pola yang memfasilitasi dan mensimbolisasi peran sosial tersebut (Solomon, 1988: 233-258). Makna-makna yang seorang miliki dan perankan pada suatu posisi sosial itulah kemudian menjadi identitas diri, seperti sebagai orang tua, anak, suami atau isteri, tunangan, pelajar, pegawai. Identitas diri menunjuk lebih dari lokasi diri atau self-location dalam struktur sosial; juga merujuk pada gambar diri atau self image yaitu lualitas, sifat dan karkaterisitik lain yang aktor lihat pada dirinya sendiri (Hewit J. P., 1994: 113-114). Contohnya:

Suami dan isteritidakmenerima satu denganyang lain dalam pengertian lokasi mereka dalam keluarga, tetapimenerimasatudengan yanglain sebagai yangmengasihi, berkompetisi, eksploitif, sensitifatau dalam pengertian sifat dan karakteristik(Hewitt, 1994:113).

Identitas diri sebagai pengambilan peran berarti apa yang masuk dalam pikiran ketika seseorang memikirkan peran tertentu seperti menjadi pemimpin religius namun mendapat lebel sebagai paranormal. Pengetahuan dalam pengambilan peran bervariasi menurut usia, gender, kelas sosial, lokasi geografis dan lain-lain. Pengetahuan dalam identitas diri juga bermakna aktor menilai betapa baik atau buruknya mereka. Penerimaan diri didefinisikan sebagai sikap positif dan negatif terhadap suatu objek yaitu diri. Menurut Owens (1993: 288) sikap positif penerimaan diri ialah menghargai dan perasaan layak pada diri. Sikap negatif ialah kurang menghargai diri dan fokus pada kelemahannya. Timothy Owens (1993: 289) membagi penerimaan diri dalam, indikator self confidence dan self deprecation. Self confidence dihubungkan dengan issu pengembangan diri atau self development dan perilaku pososial. Self deprecation dihubungkan dengan keadaan menderita, isolasi dan ketergantungan.

Setiap individu memiliki kumpulan pengetahuan tentang pengambilan peran. Pengetahuan tersebut tidak saja yang positif mengenai peran tersebut tetapi juga yang stereotip atas peran tersebut, dan menyatakan bahwa "peran ini bukanlah tipe saya". Proposisi untuk hal ini ialah:

Pl: Selama fase prasosialisasi, pengambilan peran pemimpin religius yang menjalankan pelayanan penyembuhan dan pengusiran setan adalah mengumpulkan pemahaman yang positif maupun stereotip atas peran tersebut. 
Tahap prasosialisasi ini serupa dengan tahap interpersonal menurut Robert kegan yaitu anak mulai menghargai orang lain, mulai timbul rasa bersalah, malu dan berempati.

\section{b. Penemuan atau diskoveri}

Diskoveri peran terjadi ketika seseorang mengevaluasi peran tersebut untuk mengeksplorasi pertanyaan "apakah tipe peran ini yang saya suka untuk mencapainya?" Contohnya, "haruskah saya menjadi seorang pemimpin religius yang menjalankan palayanan penyembuhann dan pengusiran setan sekalipun mendapat lebel sebagai paranormal atau dukun?" Diskoveri berakhir ketika seseorang membuat keputusan/komitmen implisit atau eksplisit untuk mengembangkan identitas (saya akan melibatkan diri secara aktif dalam kegiatan penyembuhan dan pengusiran setan sekalipun mendapat lebel sebagai paranormal atau dukun). Menurut Robert Kegan tahap ini disebut pula sebagai tahap institusionl yaitu anak menyadari suatu prinsip yang menolong menentukan apa yang menjadi prioritas.

P2: Selama tahap diskoveri, pemimpin religius mulai memiliki nilai, komitmen dan prinsip yang lebih permanen untuk mengembangkan perannya sebagai penyembuh dan pengusir setan dalam kehidupan lembaga masyarakat sekalipun dilebel sebagai paranormal atau dukun.

Diskoveri peran didukung oleh perubahan status (Andreasen, 1984:784-794), dan kontak dengan seseorang yang memiliki identitas peran tersebut. Pengambilan peran termasuk konsep bahwa aktivitas pelayanan penyembuhan dan pengusiran setan adalah "sesuatu yang selalu saya inginkan" (Celsi, et al., 1993: 1-23).

Kebanyakan diskoveri identitas peran bersumber dari pengaruh luar atau kontak dengan orang lain yang memiliki identitas peran tersebut dan menawarkan perpektif yang dapat diterima mengani identitas tersebut. Orang lain yang memiliki identitas peran tersebut dapat menggambarkan mengenai karakteristik kompetensi perilaku identitas tersebut. Jembatan orang lain sangat penting memberi kesempatan bagi pribadi yang sedang mengeksplorasi peran untuk mengalami dan pada tahap awal meneladani perilaku orang lain yang berhubungan dengan identitas peran tersebut. George Herbert Mead menyebut tahap ini sebagai tahap persiapan atau The Preparatory Stage. Tahap ini sebagai tingkat persiapan, sebab benar-benar peniruan murni, dan objek-objek sosial termasuk diri sendiri belum didefinisikan dengan katakata yang memiliki arti (Soeprapto, 2002: 209). Murphy menceritakan dengan sangat menarik gambaran perilaku anak di tahap persiapan ini sebagai berikut:

Bayi usia 6 atau 8 bulan belum memahami dirinya secara jelas. Dia bahkan tidak memahamibatasan-batasan tubuhnya. Tangannya menjangkau segala hal yang dapat dimasukkan ke dalam mulutnya dan merasakan kesenangan dengan berbuat hal itu. Ketika ibu jarinya dimasukkan ke mulut orang lain, dia mengangis karena ibu jarinya hilang, tidak kelihatan. Dia menarik-narik ibujarikakinya hingga terluka namuntidak mengerti apa yang terjadi (Mackie, 1987: 124-125). 
P3: kebanyakan diskoveri identitas diri pemimpin religius yang dipilih bersumber dari pengaruh eksternal, seperti jembatan orang lain yang mempengaruhi perkembangan pengambilan peran dan komitmen sosial seperti menjalankan pelayanan penyembuhan dan pengusiran setan.

Individu mengevaluasi peran selama fase diskoveri. Evaluasi peran ialah bagaimana peran melengkapi dan memgembangkan identitas lain yang melekat pada individu tersebut. Seseorang yang sedang mengambil peran pemimpin religius yang menjalankan praktek penyembuhan dan pengusiran setan akan mengevaluasi perannya itu apakah dapat sesuai dengan identitas keluarganya dan identitas yang berhubungan dengan profesinya yang lain atau aktivitas sehari-harinya. Evaluasi peran memberikan persepsi apakah peran tersebut adalah "untuk saya" sekarang, atau di masa depan. Pengambilan peran merupakan dasar bagi diskoveri identitas untuk mengevaluasi dan mulai mengembangkannya. George Herbert Mead menyebut tahap ini sebagai tahap permainan atau The Play Stage. Tahap ini dimulai usia 3 tahun dan berakhir di usia masuk sekolah (Mackie, 1987: 128). Menurut Stone, tahap permainan memiliki dua fungsi sosialisasi.

Pertama, melalui permainan drama anak memahmi dirinya dariperspektiforang lain.

Kedua, permainantersebutmenjadi sarana antisipasi sosial sebagaianakdalammengambil

peran akan dimilikinya pada kehidupannya di masa yang akan datang (Mackie, 1987:

132).

P4: Pengambilan peran menuntun eksplorasi awal pemimpin religius atas aktivitas penyembuhan dan pengusiran setan yang berkaitan dengan identitasnya.

Jika setelah eksplorasi individu memutuskan "peran itu bukan untuk saya", maka informasi atas pengalaman peran akan tetap tinggal dalam individu. Jika pemgalaman-pengalaman selama eksplorasi memberikan persepsi bahwa peran itu sesuai dengan pribadinya, individu akan suka mengembangkan peran tersebut ke tahap konstruksi peran. Seseorang dapat terus mengembangkan perilaku yang berkaitan dengan identitas peran sekalipun terputus dengan pengaruh sosial atau tidak lagi berhubungan dengan orang lain yang memiliki identitas peran tersebut.

\section{c. Konstruksi Identitas}

Individu dalam konstruksi identitas mengumpulkan pengalaman dengan produk-produk dan pola-pola perilakuyang berhubungan dengan peran. Konstruksi identitas terjadi dalam konteks jaringan sosial yang menguatkan identitas atau malah melemahkan identitas (Homer, 1984: 255-262; Kleime, et al., 1993: 209-235). George Herbert Mead menyebut tahap ini sebagai tahap pertandingan atau The Game Stage: Tahap ini dimulai usia 7 tahun hingga pubertas (Mackie, 1987: 133). Jika tahap permainan, anak mampu menggabungkan seluruh significant others yaitu mengertiperspektifdaribeebrapa individulain secarabersamaan, maka tahap pertandingan, anak menerima generalized others atau penyemarataan orang lain yaitu peraturan, 
perspektif dan definisi masyarakat yaitu significant othersitu tidak hanya dimengerti tetapi juga menjadi miliknya (Mackie, 1987:133).

Artinya sosialisasi pada tahap ini membuat segala sesuatu yang pertama kali berada di luar individu kini berada di dalam individu, melalui proses role taking atau mengambil peran dan roleplaying atau memainkan peran.

Role taking dalah kemampuan memperkitakan peranan orang lain untuk selanjutnya meniru peran yang dibawakan orang itu. Roleplaying ialah anak yang membawakan peran akan terus memainkan peran itu, dan peran itu menjadi dirinya, dan berlaku dengan cara yang konsisten dengan profesi itu (Cohen, 1983: 102).

Tahap pertandingan atau tahap generalized others ini dijelaskan oleh Metzer dan Petras sebagai berikut:

Setelah mencapai sudut yang digeneralisasi, seorang individu dapat mengontrol dirinya sendiridalam tingkah laku yang konsisten dan tersusun. Dia dapat memandangdirinya sendiri dari satu sudut yang konsisten. Ini berarti, individu tersebut dapat melebihidefinisi yang berhubungan dengannya. Ilustrasi untukhal ini mungkin yang tergambar dalam situasidimana seorangInggris berpakaian rapi untukmenghadiri makan malam di tengah belantara Afrika. Jadi, dengan memilikigeneralized others, seorangindividu terbebas dari takanan-tekanan keanchan situasi mendadak. Dia dapat bertindak dengan jumlah konsisten tertentu dalam pelbagai situa si karena tindakannya ini berhubungan dengan harapandan definisi yang telah diinternalisasiolehnya (Soeprapto, 2002:214).

P5: Selama konstruksi identitas, pemimpin religius mengerti perspektif orang

lain sekaligus menerima menjadi miliknya.

Menurut Robert Kegan tahap konstruksi ini disebutnya sebagai tahap interindividual, seseorang mulai belajar keanekaragaman sistem nilai di samping sistem nilainya sendiri. Seseorang yang mencapai kedewasaan sosial interindividual dapat berpegang pada sistem nilainya sendiri namun pada saat yang sama juga berpegang pada sistem nilai lintas budaya, dan melihat persoalan dari berbagai perspektif tersebut.

Identitas adalah status yang terintenalisasi. Status adalah rangking atau posisi dalam suatu kelompok atau oragnisasi. Ada beberapa jenis status:

Statusyang diberikanatau ascribed statuses yaitu diperoleh sejak lahir berdasarkan jenis kelamin, usia, ras, kelompoketnis dan latar belakang keluarga. Statusyang dicapaiatau achieved statutesyaituyangdiperoleh sebagai hasildaripengetahuan, kemampuan bekerja, ketrampilan dan ketekunan (Gerald R. Leslie, R. F. Larson dan B. L. Gorman, 1980: 149-150).

Tahap konstruksi, individu yang sedang mengambil identitas peran sebagai pemimpin relgius yang menjalankan praktek penyembuhan dan pengusiran setan mengumpulkan seperangkat kepemilikan dan keahlian yang dipertimbangkan dapat mendukung aktivitas yang berkaitan dengan peran identitasnya itu.

P6: Sealama konstruksi identitas, proses pengambilan peran pemimpin religius yang menjalankan pelayanan penyembuhan dan pengusiran setan 
menuntun kepada penampilan identitas, termasuk penggunaaan kepemilikan.

Pemimpin religius dalam mengumpulkan pengalaman dengan produk-produk dan pola-pola perilaku yang berhubungan dengan peran penyembuhan dan pengusiran setan dinyatakan dalam pemikiran "bagaimana saya mengembangkan peran ini," termasuk apa produk yang digunakan, bagimana menggunakan produkprodukitu, dan dari mana sertt bagaimana mendapatkan produk tersebut. Pemimin religius tersebut mulai memikirkan identitas yang ideal, "bagaimana seharusnya saya sebagai tipe pribadi yang sedang menjalankan pelayanan penyembuhan dan pengusiran setan."

P7: Selama konstruksi identitas, pemimpin religius menjadi lebih mengembangkan pengetahuan tentang apa produk/merek dari benda-benda yang digunakan atau dikenakan sebagai pelaku penyembuh dan pengusir setan, bagaimana menggunakan produk atau benda-benda tersebut, dan dari mana dan bagaimana mendapatkan produk-produk atau benda-benda tersebut.

d. Pemantapan (maintenance)

Konstruksi identitas adalah suatu periode perubahan, tahap selanjutnya ialah periode pemantapan. Jaringan sosial yang mendukung identitas semakin terbuktikan pada tahap ini. Identitas ideal mencapai keadaan kedewasaan secara relatif, merefleksikan identitas yang berhubungan dengan kepemilikan dan ketrampilan yang diakumulasikan oleh individu. Identitas pada tahap ini terintegrasi dalam diri individu.

Akumulasi kepemilikan dalam tahap ini semakin menunjuk pada produk yang lebih moderen, lebih mampu memenuhi banyak kebutuhan. Akumulasi pengalaman individu atas identitas merujuk pada pemantapan pemahaman atas identitas. Pemahaman itu dapat berupa pemahaman mengenai apa perlengkapan dan aksesorisnya yang sesuai atau yang merefleksikan identitas idealnya sebagai penyembuh dan pengusir setan.

P8: Tahap pemantapan, pemimpin religius menjadi lebih mantap dalam memahami kumpulan produk yang sesuai dengan identitasnya sebagai penyembuh dan pengusir setan.

P9: tahap pemantapan, individu menjadi lebih mantap dalam menguasai ketrampilan yang sesuai dengan identitasnya sebagai penyembuh dan pengusir setan.

e. Hambatan Identitas

Ada dua tipe hamabtan identitas: latensi dan disposisi atau penyusunan identitas.

(I) Latensi

Latensi menggambarklan fase individu berhenti melanjutkan aktivitas, perilaku dan mengurangi akumulasi kepemilikan yang berhubungan dengan identitas. Individu pada tahap latensi membuat kesimpulan "saya tidak pernah 
menjadi tipe pribadi ini." Kesimpulan ini timbul karena peran pemimpin religius sebagai penyembuh dan pengusir setan dipandang sebagai penyimpangan yaitu dieap paranormal atau dukun.

(2) Disposisi Identitas

Disposisi identitas meggambrakan situasi individu bermaksud menghapus identitas dari pikirannya. Jaringan sosial yang berhubungan dengan identitas turut "dihentikan." Kepemilikan yang berhubungan dengan identitas juga didisposisi. Individu pada tahap disposisi mengatakan bahwa "apa yang menjadi identitas saya dulu kini tidak lagi." Disposisi identitas mengandung unsur nostalgia atau kenangan lama, juga mengandung unsur rasa malu atau penyesalan pengembangan identitas yang ideal tidak pernah tercapai. Disposisi identitas termasuk pengunduran diri, penyesalan, frustrasi atau memandang identitas tersebut sebagai yang tidak realistik.

P10: Kepemilikan yang berhubungan dengan identitas penyembuh dan pengusir setan yang terdisposisi merefleksikan emosi seperti kesedihan, rasa malu atau kenangan lama (nostalgia) atas peran penyembuh dan pengusir setan yang telah dimainkannya itu

Tahap disposisi ini menurut Erikson ialah pengalaman konflik, jika ditangani dengan berhasil akan mengembangkan identitas diri, jika tidak berhail seseorang akan gagal mengembangkan identitas dirinya.

\section{KESIMPULAN}

I. Keberhasilan pencapaian identitas diri yang dilebel sebagai penyimpangan ternyata melibatkan beberapa tahap dan beberapa faktor. Menurut teori siklus identitas sosial ada beberapa tahap dan setiap tahap mengandung beberap faktor yang terlibat dalam menentukan pencapaian identitas diri. Tahap prasosialisasi terdapat faktor selfdeprecation dan self confidence. Tahap penemuan atau diskoveri mengandung faktor evaluasi, komitmen implisit atau eksplisit, kontak dengan orang lain yang memiliki identitas peran sama, memiliki konsep peran yang dimainkan. Tahap konstruksi mengandung faktor tahap pertandingan, pengetahuan dan penggunaan produk atau barang kepemilikan yang mendukung peran yang dimainkan. Tahap latensi terdapat faktor penghentian aktivitas. Tahap disposisi atau penyusunan mengandung faktor nostalgia/kenangan lama, rasa malu, kesedihan, pengunduran diri, penyesalan, frustrasi, memandang identitas tersebut sebagai tidak realistik. Tahap pemantapan (maintenance) terdapat faktor akumulasi ketrampilan dan kepemilikan yang sesuai dengan identitas.

2. Pemimpin religius yang mendapat lebel peyimpangan dari masyarakat atas peran penyembuhan dan pengusiran setan yang dimainkan dapat menggunakan siklus identitas sosial ini dalam mengevaluasi perannya dan penilaian masyarakat atas peran yang dimainkannya sehingga keputusan yang diambil berkaitan dengan peran dan identitas dirinya dapat menjadi lebih objektif. 


\section{DAFTAR PUSTAKA}

Andreasen, Alan R., 1984, "life Status Changes and Changes in Consumer Preference and Satisfaction" dalam Journal of Consumer Research, llDesember, 784-794

Cavendish, Richard, 1985, "Magic", dalam Man, Myth, \& Magic: The Illustrated Encyclopedia of Mythology, Religion and the Unknown, Vol. 6. Marshall Cavendish, New York.

Cohen, Richard L., Randall L. Rose, Thomas W. Leigh, 1993, "An Exploration of High-Risk Leisure Consumtion Through Skydiving”, dalam Journal of Consumer Research, 20 June, 1-23.

Cohen, Bruce J., 1983, Sosiologi suatu Pengantar, Bina Aksara, Jakarta.

Dombec, Marc. Robert Kegan's Awesome Theory of Social Maturuity (http:// MentalHelp.Net) diakses 22 Oktober 2007

Elwood, Robert S., 1982, Many People, Many Faith, 2nded., Prentice Hall, Inc., Engelwood Cliffs, $\mathrm{Nj}$.

Fajar. 18 September 2007. Britney Spears Diusir dari Hotel Mewah. Halaman 32.

Fajar. 18 September 2007. Kapolres Tator Dilapor Aniaya Warga. Halaman 26.

Fajar. 24 September 2007. Ketua BEM Pukul PD III Unismuh. Halaman 25.

Fajar. 27 September 2007. Pengawas Hakim Ditangkap. Halaman 1, 11.

Fajar. 17 Oktober 2007. Kapolda Copot Kapolres Bantacng. Halaman 1, ll

Fajar. 6 Noivember 2007. Dosen FISIP Unhas Adu Jotos. Halaman 31.

Guijarro, Santiago, 1999, "The Politics of Excorcism: Jesus' Reaction to Negative Labels in the Beelzebul Controversy", dalam Biblical Theology Bulletin, 22 September

Haviland, William A., 1983, Cultural Anthropology, 4thed, Holt, Rinehart and Winston, New York.

Hewitt, J. P., 1994, Self and Society: A Symbolic Interactionist Social Psychology, Allyn and Bacon, Massachussets.

Hoelter, Jon W., 1984, "Relative Effects of Significant Others on Self-Evaluation" dalam Social Psychology Quarterly, 47, 255-262.

Hogan, Robert dan Robert, Brent W. 2004. A Socioanalytic Model of Maturity dalam Journal of Career Assessment. Vol. XX. No. X. 2004. Halaman 1-11.

Homans, P. 1979. Jung in Context:Modernity and the Making of a Psychology The University of Chicago: Chicago.

Http://en.wikipedia.org/wiki/sociology_of_deviance. Diakses tanggal 28 Februari 2008.

Hugg, M. A., dan Vaughan, G. M., 2002, Social Psychology (3rd ed), Prentice Hall, London.

Kimball, Linda Amy, Dale McGinnis, Shawna Craig, 1986, Anthropological World: An Introduction to Cultural Anthropology, Kendall/Hunt Publishing Company, Dubuque. 
King, Francis, 1985, "Trance", dalam Man, Mythe Magic: The Illustrated Encyclopedia of Mythology, Religion and the Unknown, vol. 1I, ed. Richard Cavendish, Marshall Cavendish, New York.

Kleine, Robert., III, Susan Schultz Kleine, Jerome B. Kernan, 1993, "Mundane Consumtion and Self: A Social-Identity Perspective" dalam Journal of Consumer Psychology, 2 (3), 209-235.

, "Consumption and Self-Schema Changes Throughtout the Identity Project Life Cycle" (http://greenspun.com/com/GentlEye/ articles/id/cycle/id cycles2.html) diakses 28 Februari 2008.

Leslie, Gerald., Larson, R. F., Gorman, B. L., 1980, Introductory Sociology: Orderand Changes in Society, Third dition, Oxford University Press, New York.

Lessa, William A., Evon Z. Vogt, ed. Reader in Comparative Religion: An Anthropological Approach, Harper \& Row, Publishers, New York.

Lommel, Andreas, 1982, "Shamanism: the Beginning of Art", hal. 11-12, dalam Many People, Many Faith, Prentice Hall, Engelwood Cliffs, NJ.

Mackic, Marlinc. 1987. Constructing Women and Men. The University of Calgary: Calgary.

Murphy, Robert F., 1986, Culturulund sind Anthropology: An Overview, Prentice Hall, Inc., Engelwood Cliffs, $\mathrm{Nj}$.

Nida Eugene A., 1982, Customs and Cultures: Anthropology for Christian Missions, William Carcy Librury, South Pasadena, CA.

,1978, "Religion: Commication with the Supernatural" dalam Readings in Missionary Anthropology II, ed. William A. Smalley, William Carey Library, South Pasadena, CA.

Owens, Timothy J., 1993, "Accentuate the Positive, and the Negative: Rethinking the Use of Self Esteem, Self-deprecation \& Self-confidence", dalam Social Psychology Quarterly, 58: 288-289.

Rakoczi, Basil lvan, 1985, "Divination", dalam Man, Myth o Magic: The Illustrated Encyclopedia of Mythology, Religion and the Unknown, vol. 3, ed. Richard Cavendish, Marshall Cavendish, New York.

Reasoner, Robert W., Extending Self-Esteem Theory and Research.

Rosman, Abraham, Paula G Rubel, 1985, The Tapestry of Culture: An Introduction to Culture Anthropology, $2^{\text {nd }}$ ed., Random House, New York.

Salkind, Neil J. 1981. Theories of Human Development. Brooks/Cole Publishing Company: Monterey.

Soeprapto. H. R. Riyadi. 2002. Interaksionisme Simbolik: Perspektif Sosiologi Modern, Averroes Press: Yogyakarta.

Solomon, Michael R., 1988, "Maping Product Constellation: A Social Categorization Approach to Consumption Symbolism", dalam Psychology and Marketing, 5, 233-258.

Starke, Rodney, 2007, Sociology, 10th ed., Thomson Wadsworth, Belmont, CA. 
Stets, Jan E., dan Peter J. Burke, A Socioloical Approach to self and Identity, (http:// www.people.for.harvard.edu/-johnston/burke.pdf) diakses tanggal 4 Agustus 2008.

Sunarto, Kamanto. 1993. Pengantar Sosiologi. Fakultas Ekonomi Universitas Indonesia: Jakarta.

Tajfel, H., dan Turner, J. C., 1979, "An Integrative Theory of Intergroup Conflict". Dalam The Social Psychology of Intergroup Reiations, Brooks-Cole, Monterey, CA

Tribun Timur. 20 September. Jaya Sose Dituntut Dua bulan Penjara. Halaman 12.

Wagner, Kendra Van. Psychososial Development in Infancy and Early Childhood (http:// psychology.about.com/od/theories of personality/a/psychosocial.htm) diakses 22 Oktober 2007

Winick,Charles, 1956, Dictionary of Anthropology, Philosophical Library, Inc, New York. 